\title{
Prerequisites for the effective fight against hate crimes
}

\author{
PETRA BÁRD ${ }^{1,2 *}$ \\ ${ }^{1}$ Department of Criminology, Faculty of Law, Eötvös Loránd University, Budapest, Hungary \\ ${ }^{2}$ CEU Democracy Institute, Budapest, Hungary
}

ORIGINAL RESEARCH PAPER

Received: November 11, 2020 • Accepted: November 11, 2020

Published online: October 19, 2021

(c) 2020 The Author(s)

\begin{abstract}
Hate crimes poison societies by threatening individual rights, human dignity and equality. They effect private lives, or even victims' life and limb. Due to their ripple effect, they terrify whole communities, reinforce tensions between social groups, ultimately jeopardising peaceful coexistence. No society is immune from the signs of hatred, but whether they get tamed or whether prejudices are deepened, depends on the social measures that are applied vis-à-vis the phenomenon. The state's reaction creates norms and will informs society about the current acceptable standards. European expectations help forming these. Standards developed by the European Court of Human Rights include the obligations to ensure that hate against social groups as a motivation is considered an aggravating circumstance or leads to penalty enhancement. States must also ensure that national investigation authorities show special vigilance to explore and unmask the bias motives behind hate crimes. Such European expectations still leave a wide room of manoeuvre to respond to hate crimes efficiently and dissuasively. But irrespectively of the national codification method, for legal provisions to reach the desired outcome, certain social preconditions must be met. For hate crime laws or provisions to work, states must reach a certain level of maturity from the viewpoint of democracy, fundamental rights in general and the rule of law, where guaranteeing judicial independence is an absolute minimum.
\end{abstract}

\section{KEYWORDS}

hate crimes, bias criminality, prejudice, hatred, latency

*Corresponding author. E-mail: Bardp@ceu.edu 
This issue is dedicated to the memory of Professor Andrea Kozáry, a prominent scholar and our valuable ally in the fight against bias criminality.

\section{INTRODUCTION}

The majority of papers in this semi-thematic special volume discuss hate crimes. The contributors are members of the SPECTRA Research Group established at the Department of Criminology in the Faculty of Law at Eötvös Loránd University, following the Hungarian Academy of Sciences' Lendület (English: Momentum) excellence program being awarded to the Author. The research team explores the social prerequisites for the effective fight against hate crimes through criminal law means and minority rights protection. This volume provides a hate crime literature review from the viewpoints of various disciplines and branches of laws: sociology, criminology, international law, criminal law, anti-discrimination law and free speech law. ${ }^{1}$

\section{CONCEPTUAL CLARITY}

'Hate crime' is a criminological concept and an umbrella term that refers to a group of crimes as defined by national criminal laws. Accordingly, a hate crime is not one particular offence instead it can take many forms from damaging property to killing people.

According to the authoritative definition of the Organization for Security and Co-operation in Europe (OSCE), hate crimes are 'criminal offences committed with a bias motive'. ${ }^{2}$ Hate is often the motive behind criminality e.g., crimes committed out of jealousy or revenge. The perpetration of hate crimes, however, is fuelled by hatred against the group to which the victim belongs and this is the sole or primary motivation behind the crime. Hate crimes are message crimes where the perpetrators wish to make their prejudices clear towards the victim's community. The genealogy of social hatred, its social, political, cultural contexts and factors that facilitate the occurrence of hate crimes are discussed in detail by Ildikó Barna in the present volume.

For the criminologist and the criminal lawyer, both the crime and the bias motive elements of the OSCE definition are equally important. The first element of a hate crime is an act that constitutes a crime under ordinary criminal law - this is the base offence. Many crimes may qualify as base offences and in theory they may include any criminal offence against persons or property or the public peace, including manslaughter, assault, harassment, damage to property, hooliganism. The gravity of the criminal offence is irrelevant as hate crimes can take many forms from petty crimes through assault to manslaughter. The spectrum of base crimes varies from jurisdiction to jurisdiction, as national substantive criminal law provisions show great differences in this regard.

Acts do not qualify as a hate crime if there is a bias motive only. One such example is discrimination; another hate speech. Discrimination refers to a less favourable treatment of

\footnotetext{
${ }^{1}$ Authors in this volume owe special thanks to Professors Károly Bárd, Andrea Kozáry, Veronika Nagy, András László Pap, Gábor Polyák and Zsuzsanna Vidra for their insightful reviews. The present paper was authored in the framework of the MTA-ELTE Lendület SPECTRA Research Group (Social prerequisites for the effective fight against bias-motivated crimes through criminal law and minority rights protection, contract number: LP2018-9/2018).

${ }^{2}$ Organization for Security and Co-operation in Europe, Ministerial Council, Decision No. 9/09 Combatting Hate Crimes, MC(17) Journal No. 2, Agenda item 8, 2 December 2009.
} 
individuals, whether in employment, education, vocational training or access to goods and services) on the basis of certain protected characteristics. Discrimination may pave the way to hate crimes but discrimination alone does not qualify as a hate crime as unjustified differentiation is typically covered by civil or administrative law and such an act does not amount to a crime under the criminal code. Hate speech is the other schoolbook example of bias motivated behaviour not amounting to hate crime. The human behaviour underlying hate speech is speech which is not a crime, but a constitutionally protected human act. Lacking a base crime, these behaviours are not regarded as hate crimes, even when they are criminalised. ${ }^{3}$ Irrespective of their labelling, these manifestations of social hatred can be left unanswered. However, both discrimination and also certain forms of hate speech might be the stepping stones to violent hate crimes, these behaviours must be addressed by the state, so as not to allow minor manifestations of hostility have a ripple effect and escalate into violent bias crimes. ${ }^{4}$ Judit Bayer has extensively dealt with a significant aspect of hate speech, namely hate speech by persons of authority, assessing it against the protection of political speech and the high impact it may have on social hatred.

The second element of a hate crime is the bias, which motivates the perpetrator. This element distinguishes bias hate crimes from ordinary crimes. The bias motive is the perpetrator's prejudice towards the victims, premises or other target of the offence, which are chosen because of their real or perceived connection, attachment, affiliation, support of or membership with a protected group. Protected characteristic typically include, but are not necessarily limited to, race, ${ }^{5}$ national or ethnic origin, language, colour, religion, sex, age, mental or physical disability, sexual orientation. The bias may also be triggered by other factors.

Hate crimes have a considerably greater impact than ordinary crimes on the direct victim, the victim's community and society as a whole.

Victims of hate crimes are often targeted for an immutable, unchangeable characteristic or an element of their core identity and thus the impact of the crime, the feeling of vulnerability, helplessness and hopelessness on the side of the direct victim may be particularly grave. ${ }^{6}$ The act also has a severe impact on the wider community, the targeted group, which typically is a historically disadvantaged one or a minority in the sense of a powerlessness. ${ }^{7}$ In addition, hate crimes erode societal cohesion, reinforce social tensions and trigger retaliation that results in a vicious circle of violence and counter-violence. The incited negative emotions fuel arbitrariness and abuse of rights, which endanger the rule of law. These special characteristics offer good

\footnotetext{
${ }^{3}$ This is the general rule. There is a minority of hate speech acts however, where the speech itself is a crime, regardless of the perpetrator's motivation, such as for example incitement to violence. In this case the same crime committed with a bias motive, will qualify as a hate crime.

${ }^{4}$ Perry-Alvi (2012) 57-71. See also Gordon Allport's (1954) 'Scale of Discrimination and Prejudice', which differentiates between the following stages depending on the harm: the cause, starting with the least violent form: anti-locution, such as making jokes or expressing hateful opinions about a certain group and its members; avoidance leading to isolation and exclusion; discrimination. Allport later inserted at this point aggression, as an assumption of hierarchy of power; physical attacks, which are considered by law as hate crimes; and extermination. Allport also emphasized the importance of early intervention to prevent the escalation of hostility.

${ }^{5}$ There is one human race only. We will however adhere to this outdated and scientifically dubious term, since this is what legal documents use.

${ }^{6}$ Iganski (2001) 626-38; Iganski and Lagou, S (2014).

${ }^{7}$ Perry (2014).
} 
enough reasons for addressing hate crimes differently than ordinary crimes and in fact states are bound to treat bias motivated crimes differently by way of international law. These state obligations are complemented by a series of international soft laws. For a detailed account of hate crimes and international institutions see the literature review by Eszter Kirs in this volume. In the following supranational expectations will be enumerated with a European focus.

\section{EUROPEAN EXPECTATIONS}

States, according to the Council of Europe and especially the European Convention on Human Rights (ECHR) as interpreted by the European Court of Human Rights (ECtHR), have an obligation to treat hate crimes differently than base crimes.

The ECHR addresses the prohibition of discrimination in its Article 14 and Protocol 12. ${ }^{8}$ Hate crimes are extreme manifestations of discrimination and these provisions are of utmost relevance in tackling bias criminality. According to Article 14 ECHR 'The enjoyment of the rights and freedoms set forth in this Convention shall be secured without discrimination on any ground such as sex, race, colour, language, religion, political or other opinion, national or social origin, association with a national minority, property, birth or other status.' (emphasis added)

It is apparent from the wording that Article 14 can only be invoked in conjunction with another Convention right. In case of hate crimes, the relevant substantive rights are Article 2 of the ECHR on the right to life and Article 3 on the prohibition of torture and inhuman or degrading treatment. Article 8 on private life has also been invoked in hate crimes cases. It can be derived from the ECtHR case-law that rights enshrined in these articles trigger both negative but also positive obligations on states, i.e. they must not only refrain from interference but they have the 'obligation to do something. . Positive obligations have both a substantive and a procedural prong. The ECHR expressly calls states to ensure the full enjoyment of the rights guaranteed: domestic authorities must investigate and respond to rights violations. In relation to crimes, the ECtHR developed the doctrine of states' positive obligation to conduct effective investigations. These rights read in conjunction with Article 14 of the ECHR led to a rich case-law on responding to hate crimes in the last 15 years. According to the Strasbourg jurisprudence, states must insert penalty enhancements for hate crimes in national criminal codes; show special vigilance to explore and unmask racist motives behind crimes; explore bias motives behind crimes committed by private parties; unmask other bias motives behind crimes; acknowledge mixed motives; and protect those who can be associated with someone having a protected characteristic. ${ }^{10}$

European Union law also obliges Member States to tackle hate crimes. The Lisbon Treaty lists values which member countries undertook to respect and promote (Articles 2 and 3(1) of the Treaty on the European Union, TEU). These are human dignity, freedom, democracy, equality, the rule of law and respect for human rights, including the rights of persons belonging to minorities. The Lisbon Treaty's point of departure is the presumption that these values are common

\footnotetext{
${ }^{8}$ Protocol 12 is in force in relation to the - at the time of writing the present paper - 20 states including 10 EU Member States that have ratified it. https:/www.coe.int/en/web/conventions/full-list/-/conventions/treaty/177/signatures? auth=TAckiFzJ (all hyperlinks last accessed on 2 November 2020).

${ }^{9}$ Akandji and Kombe (2007) https://www.echr.coe.int/LibraryDocs/DG2/HRHAND/DG2-EN-HRHAND-07(2007).pdf.

${ }^{10}$ Kirs (2017) 141-51.
} 
to the Member States, where pluralism, non-discrimination, tolerance, justice, solidarity and equality between women and men prevail. ${ }^{11}$ Article 6 TEU moves ECHR law into the European Union legal domain, so the Strasbourg case-law related to hate crimes should also be guiding the EU legislator. According to Article 10 of the Treaty on the Functioning of the European Union (TFEU) when defining and implementing its policies and activities, the EU must aim to combat discrimination based on sex, racial or ethnic origin, religion or belief, disability, age or sexual orientation. Article 19 of the TFEU authorises the EU to take appropriate action to combat discrimination on a number of listed grounds. Article 67(3) of the TFEU obliges the EU to ensure a high level of security through combatting crime, racism and xenophobia.

The Charter of Fundamental Rights of the European Union expressly protects human dignity in Article 1 and lays down the non-discrimination principle in Article 21. Certain protected grounds are singled out in other Charter provisions, too, such as Article 22 on the respect for cultural, religious and linguistic diversity; Article 23 on the equality between women and men; Article 24 on the rights of the child; Article 25 on the rights of the elderly; and Article 26 on the integration of persons with disabilities. The positive state obligations derived from the various rights enshrined in the Charter, from which the right to life enshrined in Article 2, the prohibition of torture and inhuman or degrading treatment or punishment in Article 4 and the respect for private and family life incorporated into Article 7 stand out, are of special relevance for the substantive and procedural aspects of the fight against hate crimes.

Moving to secondary sources of EU law, the Union lawmaker adopted its first law against hate speech back in 1996, through its Joint action to combat racism and xenophobia, ${ }^{12}$ which was then replaced by Framework Decision 2008/913/JHA of 28 November 2008 on combating certain forms and expressions of racism and xenophobia by means of criminal law. ${ }^{13}$ This framework decision in Article 4 calls upon Member States to take the necessary measures to ensure that racist and xenophobic motivation is considered an aggravating circumstance, or, alternatively that such bias is taken into account by the courts when imposing penalties. The other relevant secondary law is Directive 2012/29/EU of the European Parliament and the Council on establishing minimum standards on the rights, support and protection of victims of crime. ${ }^{14}$ Article 22 obliges Member States to ensure that victims' specific protection needs are identified and that they determine how victims would benefit from special measures foreseen in the directive, during criminal procedures, with special regard to victims' particular vulnerability

\footnotetext{
${ }^{11}$ The presumption is increasingly being questioned. See European Commission Reasoned Proposal in Accordance with Article 7(1) of the Treaty 1162 on European Union Regarding the Rule of Law in Poland - Proposal for a Council Decision on 1163 the Determination of a Clear Risk of a Serious Breach by the Republic of Poland of the Rule of 1164 Law COM(2017)835 final; European Parliament resolution of 12 September 2018 on a proposal calling on the Council to determine, pursuant to Article 7(1) of the Treaty on European Union, the existence of a clear risk of a serious breach by Hungary of the values on which the Union is founded (2017/2131(INL)).

1296/443/JHA: Joint Action of 15 July 1996 adopted by the Council on the basis of Article K.3 of the Treaty on European Union, concerning action to combat racism and xenophobia, OJ L 185, 24.7.1996. 5-7.

${ }^{13}$ Council Framework Decision 2008/913/JHA of 28 November 2008 on combating certain forms and expressions of racism and xenophobia by means of criminal law, OJ L 328, 6.12.2008. 55-58.

${ }^{14}$ Directive 2012/29/EU of the European Parliament and of the Council of 25 October 2012 establishing minimum standards on the rights, support and protection of victims of crime, and replacing Council Framework Decision 2001/ 220/JHA, OJ L 315, 14.11.2012. 57-73.
} 
to secondary and repeated victimisation, intimidation and retaliation. The individual assessment must, as a minimum, take into account the victim's personal characteristics and the type and circumstances of the crime, with special regard to 'victims who have suffered a crime committed with a bias or discriminatory motive which could, in particular, be related to their personal characteristics'. ${ }^{15}$ In line with Article 11 of the victims' rights directive, Member States are to respect the right of victims of hate crimes to have 'a review of a decision not to prosecute' or to discontinue proceedings 'in accordance with their role in the relevant criminal justice system' ${ }^{16}$

\section{MANOEUVRING IN THE NATIONAL SETTING}

States have a large room to manoeuvre when drafting domestic laws to meet the objectives set by international standards. They have the option and obligation to opt for a codification technique, whether a sui generis hate crime law or provision, a qualifying circumstance or a sentencing provision. They also must select the base crimes which may qualify as hate crimes if committed with a bias motive. Finally, they must define groups protected by hate crime laws or provisions.

Having a sui generis legal classification for hate crimes is fundamentally symbolic. It is so for numerous reasons. Picking out a certain criminal motive by giving it an individual name is in itself a symbolic act. When they want to express a negative value judgment more emphatically, instead of leaving the assessment of the motive exclusively in the hands of the judiciary, who could use their discretion to assess on a case-by-case basis the motive either as an aggravating factor $^{17}$, legislators have the option of singling out certain criminal motives and modes by giving them concrete names, ${ }^{18}$ which is typically done in the form of qualifying circumstances. But to make the state's denouncement of the crime even more symbolic, legislators can elevate the motive to a sui generis legal classification. ${ }^{19}$

On the output side, the purpose of sentencing, it makes no difference what codification logic has been used for the legal articles referenced in the case. When there are no substantial differences, the only justification for introducing a separate legal classification for hate crimes is the symbolic expression of denouncement, which may have first a public educational and informational function vis-à-vis all citizens, but most notably to potential offenders, while second, it

\footnotetext{
${ }^{15} I d$. at Article 22(3).

${ }^{16}$ European Union Fundamental Rights Agency: FRA Opinion - 02/2013, Opinion of the European Union Agency for Fundamental Rights on the Framework Decision on Racism and Xenophobia - with special attention to the rights of victims of crime, 15 October 2013, http://fra.europa.eu/sites/default/files/fra-opinion-2-2013-framework-decisionracism-xenophobia_en.pdf.

${ }^{17}$ One such example in the Hungarian legislative material is base motive as a qualifying circumstance, which includes acts motivated by racist hatred. See manslaughter, physical harm, violation of personal liberty, libel, unlawful confinement and, in the list of military crimes, abuse of command authority.

${ }^{18}$ For example, in Andorra and the United Kingdom, the Court can take into account a racist motive as a qualifying circumstance in the case of prosecuting any crime; on top of that, in Andorra, - a xenophobic motive, as well as attacks on one's views, religion, nationality, race, sexual orientation, illness, physical or mental disability, are all taken into consideration. Andorra Criminal Code, Article 30. Paragraph (6); United Kingdom, Powers of Criminal Courts (Sentencing) Act 2000, Section 153.

${ }^{19}$ This is rather rare, see for example the Czech Criminal Code, Article 196 Paragraph (2) or the UK Crime and Disorder Act 1998, Sections 29-32. On the different models, see Novoszádek and Rácz (2009) 63-80.
} 
can also show the state's solidarity with the victims of such crimes. Thirdly, the state symbolically acknowledges that it has been unable to resolve the existing social tensions and anyone including members of the majority group - can fall victim to such acts merely through a group identity beyond their control. The precondition of all three goals, but most notably the goal of solidarity with the victims, is that the legislator develops a consistent policy for identifying specific groups that need the protection of a sui generis legal classification the most. The selection is usually based on extra-legal criteria, taking into consideration either the lessons of history or disadvantages suffered by certain groups at the time of codification.

The next issue to be decided is the type of crimes that may qualify as hate crimes. Most hate crimes target persons or property. They can cover a very wide range of crimes from hooliganism to homicide. Some countries single out specific base crimes where the bias motive may be considered, others allow to take hatred into consideration regarding all crimes enshrined in the criminal code. Some countries' legislation racist and xenophobic motivation can be considered as an aggravating circumstance of any crime. ${ }^{20}$ Other countries only list a limited number of behaviours that may qualify as hate crimes in their sui generis hate crime provisions, ${ }^{21}$ whilst others consider racist or xenophobic motivation as an aggravating circumstance with regard to certain, mostly violent crimes. $^{22}$

Protected groups, those worthy of the extra criminal law protection, must be chosen. The selection is usually based on extra-legal criteria, taking into consideration either the lessons of history or disadvantages including social marginalisation suffered by certain groups at the time of codification. Legislators can rely on several branches of laws when determining the groups to be protected. First, it can make references to international law, where certain groups enjoy increased protection in view of atrocities they had suffered earlier. Traditionally, the national, ethnic, racial or religious groups fall into this category. Criminal responsibility for genocide, which is the gravest form of hate crime, can be established only in connection with these groups. ${ }^{23}$ The scope of protection can be extended further, by taking into account the social tensions of the present. To that effect, legislators can, as a second step, rely on the regulations of other legal branches, the constitution and legal documents relating to equality and antidiscrimination. ${ }^{24}$ The third option, ideal from the viewpoint of democracy and the rule of law,

\footnotetext{
${ }^{20}$ In Italy, for example Article 604-ter ICC on ethnic, national, racial and religious hatred is applicable to all crimes punishable with a penalty other than life imprisonment (obviously penalty enhancement cannot be applied to the strictest form of criminal sanction). See also the aggravating circumstances in Act No.205/1993, the "Mancino Act".

${ }^{21}$ See Act C of 2012 on the Hungarian Criminal Code, Article 216.

${ }^{22}$ See Article 130 of the German Criminal Code on incitement of masses; Article 185 on insult; Article 211 on murder under specific aggravating circumstances.

${ }^{23}$ The Convention on the Prevention and Punishment of the Crime of Genocide was adopted by the United Nations General Assembly on 9 December 1948. The EU also protects certain groups based on past European experiences. See Council Framework Decision 2008/913/JHA of 28 November 2008 on combating certain forms and expressions of racism and xenophobia by means of criminal law.

${ }^{24}$ In order to ensure the internal coherence of the legal system, it is recommended to rely on already existing enumerations of protected group characteristics. In Hungary it is preferable to take the list of protected grounds in Article 8 of Act CXXV of 2003 on Equal Treatment and Promotion of Equal Opportunities as a starting point, since the Hungarian constitution, i.e. the respective Article XV of the Fundamental Law does not explicitly mention sexual orientation and gender identity as protected grounds, therefore they can only fall under the category 'other status' by way of interpretation.
} 
yet somewhat risky from a political perspective, is that legislators face up to and openly acknowledges the past of the given state, as well as to the existing, unresolved social tensions; generate a public debate and assumes political responsibility for the choice of the groups selected. In this way, the number of groups named in the criminal code will probably be somewhere between the numbers of groups to be protected according to the first and the second options.

Protected characteristics are typically, albeit not necessarily, immutable, unchangeable or reflect a fundamental aspect of one's identity. They are often apparent or easily noticeable to others. The formulations of these characteristics in the national criminal codes are neutral, however it might make sense for statistical data collection to single out certain groups that are typical targets of hate crime in a given jurisdiction e.g. the national criminal code might address hate crimes committed based on the ethnic origin or the religion of the victim, but the data collection might specify the Roma community or Muslims.

States might opt for a closed list of protected characteristics, specifically and exhaustively numbered or for an open list, adding 'such as' before the list or 'and other characteristics' or 'and other societal groups' after it. Both codification techniques have advantages and disadvantages. Drawing up a closed list means that the legislative power takes political responsibility for the selection of social groups and such a method also adds to legal certainty. A closed list corresponds to the state aims to express solidarity with historically or currently disadvantaged groups and an acknowledgment of the past and present disadvantages. An open list in turn will protect groups that are victims to social tensions that could not have been foreseen. This might be relevant in the case of sudden social changes. During the COVID-19 pandemic, hostility arose against social groups, such as the sick and the elderly or mask-wearing people that had not previously been victims of hate crimes. An open list would protect them. However, the symbolic message of solidarity for historical injustices is diluted by extending extra protection to a wide variety of groups. When lists are open, via an appropriate historical, contextual and teleological interpretation, the judiciary could remedy the shortcomings of the drawbacks of this codification technique. Courts could interpret the term 'certain groups of the population' as a minority without a power base; completely or almost completely unable to assert its interests; historically discriminated against and/or currently being in a vulnerable and helpless state.

Most countries do not limit the scope of protection to minority victims, whether in the sense of power or a numerical sense but hate crime laws typically cut both ways. A similar but different argument was put forward by the Hungarian Supreme Court. In their view, hate crime laws are to protect minorities, but the decisive factor is, who is in a minority in the given situation and not in society in general. ${ }^{25}$ This interpretation goes against the symbolic nature of hate crime provision to express solidarity with historically disadvantaged groups, instead it puts the social hatred into the focus as a motivation that is more harmful than others, irrespectively of the vulnerability of the victim.

Not all groups are worthy of extra protection, even within minorities. The constitutional minimum requirement is that states must not, under any circumstance, provide increased and symbolic protection to groups, whose primary group-forming identity is hatred against other groups. Those who deny the basic values of democratic government based on the rule of the law

${ }^{25}$ See the judgment in the Hungarian Tavaszmező case. Kúria, Bfv.II.590/2012/18., 7 February 2013. 
e.g., banned paramilitary groups, dissolved parties or associations denying the principles of equality and the right to equal dignity should not be entitled to the increased and symbolic protection of the law. ${ }^{26}$ Those who nurture hatred against other people, those against whom, or against whose group forming identities, the state itself is fighting, cannot receive increased protection and perpetrators assaulting them must not receive symbolic sentences. ${ }^{27}$ If members of such hate groups suffer violent crimes then the perpetrator should only be responsible for the base crime.

States must decide how to prove hate crimes in courts. According to the hostility model, hatred or animosity needs to be proven on the side of the perpetrator against the victims' group. An important factor is that victims are interchangeable; they are seen as a faceless representative of a social group against which the perpetrator has prejudices. The discriminatory selection model however, suggests that the perpetrator's selection of a victim based on prejudice against the group to which the victim belongs is decisive. In the case of the bias model, the emotional state of the defendant has to be proven, whereas according to the latter model, the act is criminalised as a hate crime, if the victim was selected due to their group membership, which places a lesser burden on the prosecution to prove.

Finally, the possible legal consequences attached to the determination of guilt should be mentioned. Hate crimes trigger harsher sanctions than base crimes, irrespective of the codification technique, in order to show state denunciation of the phenomenon. There are alternative and equally valid considerations behind attempts diverting hate crime cases from the traditional criminal justice system. State coercion and criminal justice, let alone imprisonment have all been recently questioned in terms of efficiency. Harsher punishments do not decrease criminality and at the same time they make neighbours, bystanders, potential witnesses less vigilant, in the hope that criminal justice will fix social problems. ${ }^{28}$ Prison sanctions have been subject to even greater criticism. Prisons can be seen as training sites for future criminality, where inmates become full members of the criminal subculture and upon release, they are even more angry at society than before conviction, which makes chances if reintegration very slim.

Traditional criminal justice procedures have also been attacked by critics, for allegedly being irrational, antidemocratic, too long or in case of simplified processes, in violation of procedural guarantees. Judges have not been spared in detecting the failures of criminal procedures. In particular in complex cases, the courtroom was blamed for becoming the battlefield of experts, so much so that Braithwaite talked about a 'criminal injustice system'. ${ }^{29}$ Victims' rights and interests have been pushed into the background until the 1970s, the start of the victims' rights movement. Traditional criminal justice is incapable of fulfilling its retributive task: neither towards the victim nor towards society in general. ${ }^{30}$ A consequence of criticism has led to criminal

\footnotetext{
${ }^{26}$ Cf. the Sajóbábony incident in Hungary. Supreme Court of Hungary, Bfv.II.576/2014/13, 17 December 2014. For a more extensive analysis see Danka (2009) 92-96; Bárd (2014) 29-40.

${ }^{27}$ This closely resembles the opinion of the Hungarian Helsinki Committee, which believes that 'The law cannot afford special protection to members of groups bound by ideas that violate human dignity and stand opposed to the constitution.' Available at http://helsinkifigyelo.hvg.hu/2012/03/28/pofon/.

${ }^{28}$ Braithwaite (1999) 1738; Lianos (2003) 412-30.

${ }^{29}$ Braithwaite (1996) 9-32.

${ }^{30}$ Durkheim (1997).
} 
justice shifting to alternative forms of dispute resolution. Instead of the competitive approach of the Western world, where the resolution stems from a third, outside player, parties to a restorative case are owners of their own conflict, can proactively shape the process, thereby elevating the chances of an outcome, which is acceptable to everyone and is more likely to be respected by all the parties. ${ }^{31}$ Restorative justice, e.g., victim-offender mediation, focuses on the victim, who reprivatizes the conflict, takes the perpetrator's personal history into account and in addition restores social tensions. ${ }^{32}$ It seems to be an ideal tool for resolving hate crimes, which by definition stem from social tensions. There are at the same time possible hindrances, such as the potential imbalance between the parties that make restorative justice practices ill-suited for rendering justice in hate crime cases. These considerations will be discussed in detail by Veronika Szontagh.

\section{THE SITUATION ON THE GROUND}

Criminal responsibility is relatively rarely determined despite the international obligations to show special vigilance in hate crime cases. ${ }^{33}$ This could be explained by several factors.

Cases may vanish in the reporting phase, due to lack of knowledge that the violence suffered amounts to a crime, let alone a hate crime; lack of knowledge of how and where to report the crime; a general distrust in authorities; language barriers; fear of re-victimisation; fear of retaliation by perpetrators; fear of secondary victimisation during a criminal process; fear of victim-blaming and self-blame, undocumented people being afraid of being deported or the fear of coming out in front of authorities. ${ }^{34}$

Such problems may be alleviated by a number of tools. The long-term goal of creating trust in the authorities maybe helped by online anonymous hate crime reporting channels or facilitation of the work of victim support organisations and NGOs in areas with a high density of marginalised communities. ${ }^{35}$

The investigation phase revealed a number of issues that can lead to hate crimes 'vanishing' from the authorities. These include lack of knowledge of what constitutes a hate crime on the side of the police; general lack of knowledge about minority groups and hate groups, inadequate recognition of the different victim groups that may be targeted; lack of knowledge about dealing with vulnerable victims and witnesses and a failure of witnesses to testify for reasons already mentioned in relation to reporting. It is considerably easier to prove a base crime than a hate crime results in the crime possibly being under qualified in the investigation stage. Biases held by some portion of the law-enforcement establishment may also lead to inadequate investigation of hate crimes and as a result, investigations maybe stopped or hate crime cases are framed as base

\footnotetext{
${ }^{31}$ Stuhlberg and Love (2013); Zehr (2002).

${ }^{32}$ Braithwaite (2000) 323; Christie (1977) 1-15.

${ }^{33}$ https://hatecrime.osce.org/\#participating-states.

${ }^{34}$ Balogh, Dinók and Pap (2012) 93.

${ }^{35}$ The Hungarian Working Group Against Hate Crimes can be regarded as a good practice. The Working Group also influenced the legislation, when the Hungarian Criminal Code of 2012 was adopted. For details see Pap (2018) 85-90.
} 
crimes. Prosecutors, who may wish to press on with the hate crime charges, will not be able to continue if lacking sufficient pieces of evidence.

These problems may be alleviated by trainings, by tackling possible institutional discrimination and by bias indicators, i.e. 'objective facts, circumstances or patterns attending a criminal act(s), which, standing alone or in conjunction with other facts or circumstances, suggest that the offender's actions were motivated, in whole or in part, by any form of bias. ${ }^{36}$

Specific issues may arise in the trial phase. Courts will require high standards of evidence when proving guilt. Bias indicators, e.g., the different group belonging of victim and suspect, location, date and time of the crime or the lack of any other motive, might help investigation authorities in considering bias motivation and go after them but will not be sufficient pieces of evidence in proving guilt. Therefore, courts frequently will not determine the bias motive, in lack of words spoken or written down or at least some symbols or graffities that might prove the hate motive. This again results in under-qualifying hate crimes as base crimes. In some cases, in order to pass a just judgment, judges will take the easier way out and find any other aggravating circumstance instead of having to prove bias. ${ }^{37}$ This overcautious approach is often unjustified. It might be more challenging to prove bias than more straightforward motives, such as financial gain, prosecutors regularly have to prove the mental state of suspects, when determining intent, negligence or jealousy. Bias indicators are too soft for proving the hate motive in court on their own and several indicators in conjunction with other pieces of evidence might be considered as factors pointing towards guilt in bias crimes.

The reasons behind the high latency of hate crimes, whether personal or institutional issues are expanded by Erik Uszkiewicz. If states are able to overcome these problems then hate crimes will become more visible and hate crime provisions and laws will be able to fulfil their functions of showing solidarity with the victims and express the denouncement of bias crimes. However counter intuitively, a rise in reported crimes and an increase in the number of convictions does not necessarily indicate that hate crimes are on the rise. Instead it is more often a positive sign showing a growing trust in the authorities and the gradual overcoming of problems.

\section{CONCLUSIONS}

The message which emerges from an overview of national hate crime statistics is that hate crime laws provide a relatively narrow protection for victims of bias criminality. ${ }^{38}$ This shows the limits of law and in particular criminal law in tackling severe societal problems. It also suggests that for hate crime laws or provisions to work, states have to reach a certain level of maturity from the viewpoint of democracy and the rule of law.

\footnotetext{
${ }^{36}$ Massachusetts Model Protocol for Bias Crime Investigation; cited In: OSCE, ODIHR (2014) 15. https://www.osce.org/ odihr/datacollectionguide; OSCE, ODIHR (2009) 22-26.

${ }^{37}$ Möschel (2014) 131-133.

${ }^{38}$ https://hatecrime.osce.org/\#participating-states, and against these numbers see hate crime victims' surveys and findings of the EU MIDIS and EU MIDIS II projects: https://fra.europa.eu/sites/default/files/fra_uploads/663-fra-2011_eu_ midis_en.pdf, https://fra.europa.eu/sites/default/files/fra_uploads/fra-2017-eu-minorities-survey-muslims-selectedfindings_en.pdf, https:/fra.europa.eu/sites/default/files/fra_uploads/fra-2017-eu-midis-ii-main-results_en.pdf. This was also the outcome of a legal comparison conducted for the European Parliament. See Bayer and Bárd (2020). https://www.europarl.europa.eu/RegData/etudes/STUD/2020/655135/IPOL_STU(2020)655135_EN.pdf.
} 
The first issue is law-making. One should always be careful not to have unrealistically high expectations in criminal law to solve social tensions. Modifying the criminal code is obviously cheaper, simpler and quicker than surveying the sociological, economic and historical causes of social tensions and taking effective steps and action. The codification of hate crimes however poses further challenges - the legislative is requested to protect unpopular minorities and it is very much doubtful whether a majoritarian branch of government was in the position to draft meaningful laws. Out of fear for loss of public support, it may downplay the problem, it may insist on equalizing majority and minority protection, in the sense of power, or for the same reasons it may draft an open-ended list of protected groups. The counterproductive effect is that instead of giving unpopular, historically oppressed and vulnerable groups heightened symbolic and effective protection, by way of the low number of officially recognised hate crime cases the state legally denies the everyday existence of exclusion and reduces the victims' experiences to non-existence or irrelevance. ${ }^{39}$

This is where the responsibility of the judiciary emerges. The counter-majoritarian judicial branch could in theory patch up the weak points of the law. In a state without a minimum acceptance for hate crime instruments at least within the justice system, the judiciary will not exercise its corrective function to remedy the mistakes of the lawmaker. In a society that is experiencing radicalization and is poisoned by racism, xenophobia, anti-Semitism, sexism and homophobia, hate crime laws or provisions may either remain unused or even backfire. Courts will not make those committing crimes against vulnerable citizens responsible for hate crimes, but will make minority citizens responsible when assaulting racists. ${ }^{40}$ This is when courts, putting insult to injury, invoke the provision in favour of groups denying foundational state values, such as the rule of law, equality and human dignity, against the groups that the provision was supposed to protect in the first place. Absurdly, by way of a judicial interpretation that amounts to abuse of rights, ${ }^{41}$ the state will express its sympathy with those attacking and undermining its foundational values. Ultimately through an aberrant interpretation of a hate crime provision the state becomes complicit in the majoritarian oppression of a discreet and insular minority.

Parallel with the worldwide decline concerning the trinity of the rule of law, democracy and fundamental rights during the past couple of years, ${ }^{42}$ states not only seem to fail in addressing societal hatred, but some of them are instigating hatred. The UN Special Rapporteur on contemporary forms of racism, racial discrimination, xenophobia and related intolerance has stated that political rhetoric, especially nationalist populist ideologies pose a threat to equality by fuelling discrimination and intolerance. ${ }^{43}$ Last year, before the EP election in May 2019, Members of the European Parliament felt the need to adopt a resolution on neo-fascist violence

\footnotetext{
${ }^{39}$ Möschel (2011) 1648-64.

${ }^{40}$ Bárd (2015) 93-154.

${ }^{41}$ In the meaning of Article 17 European Convention on Human Rights.

${ }^{42}$ 'More countries declined than improved in overall rule of law performance for a third year in a row, continuing a negative slide toward weakening and stagnating rule of law around the world,', https://worldjusticeproject.org/ourwork/research-and-data/wjp-rule-law-index-2020. For the entire World Justice Project Rule of Law Index 2020, https:// worldjusticeproject.org/sites/default/files/documents/WJP-ROLI-2020-Online_0.pdf.

${ }^{43}$ United Nations (UN), General Assembly: Report of the Special Rapporteur on contemporary forms of racism, racial discrimination, xenophobia and related intolerance, A/73/305, 6 August 2018.
} 
in Europe. They condemned 'hate crime, hate speech and scapegoating by politicians and public officials as they directly normalise and reinforce hatred and violence in society. ${ }^{, 44}$

A vigilant investigation into the bias motives of the crime, efforts on the side of prosecutors to prove the motive and convictions based on well drafted pieces of hate crime laws and provisions may contribute to a peaceful coexistence of various societal groups. No society is intact from the signs of hatred, but beside criminal law measures, it depends primarily on the social measures that are applied to deal with this basic human instinct, whether it gets tamed or dispersed and strengthened.

\section{REFERENCES}

Akandji-Kombe, J-F., 'Positive obligations under the European Convention on Human Rights. A guide to the implementation of the European Convention on Human Rights' (2007) 4 Human rights handbooks. Allport, G., The Nature of Prejudice (Wesley Publishing 1954).

Balogh, L., Dinók, H. and Pap, A. L., 'A jog által láthatatlan? A gyülölet-büncselekmények szabályozási kérdései és gyakorlati problémái' (Invisible through the Law? The questions and practical problems of regulating hate crimes) (2012) 4 Fundamentum 91-98.

Bárd, P., 'A gyülölet-büncselekmények büntetőjogi üldözésének jogszabályi és társadalmi feltételrendszere' (Legal and Social Conditions of the Criminal Prosecution of Hate Crimes) (2015) 75 Kriminológiai Közlemények 93-154.

Bárd, P., 'A gyülölet-büncselekmények hatékony üldözésének társadalmi feltételrendszere' [Social Conditions of the Effective Fight against Hate Crimes) in Borbíró, A., Inzelt É., Kerezsi, K., Lévay, M. and Podoletz, L. (eds.), A büntető hatalom korlátainak megtartása: A büntetés mint végsö eszköz. Tanulmányok Gönczöl Katalin tiszteletére (Keeping the Limits of Criminal Power: Punishment as a Last Resort. Studies in Honour of Katalin Gönczöl) (Eötvös Kiadó 2014) 29-40.

Bayer, J. and Bárd, P., Hate speech and hate crime in the EU and the evaluation of online content regulation approaches (European Parliament 2020).

Braithwaite, J., 'A Future Where Punishment is Marginalized: Realistic or Utopian?' (1999) 46 UCLA Law Review 1727-50.

Braithwaite, J., 'Restorative Justice and a Better Future' (1996) 76 The Dalhousie Review 9-32.

Braithwaite, J., Regulation, Crime, Freedom (Ashgate 2000).

Christie, N., 'Conflicts as Property' (1977) 17 British Journal of Criminology 1-15.

Danka, A., 'Rossz helyen lenni rossz időben, avagy mit üzennek a gyülölet-büncselekmények?' (To be at the wrong place at the wrong time, or what is the message of hate crimes?) (2009) 3-4 Föld-rész 92-96.

Durkheim, É., The Division of Labor in Society (Simon and Schuster 1997).

Iganski, P. and Lagou, S., 'The personal injuries of 'hate crime' in Hall, N., Corb, A., Giannasi, P., Grieve, J. G. D. and Lawrence, N. (eds.), The Routledge International Handbook on Hate Crime (Routlegde 2014) 34-46.

Iganski, P., 'Hate Crimes Hurt More’ (2001) 45 American Behavioral Scientist 626-38.

\footnotetext{
${ }^{44}$ European Parliament, European Parliament Resolution of 25 October 2018 on the rise of neo-fascist violence in Europe (2018/2869(RSP)), P8_TA(2018)0428. Confusingly the Hungarian translation mentions 'scapegoating of and not 'scapegoating by' politicians. The present paper relies on the English versions of EU texts.
} 
Kirs, E., 'Az Emberi Jogok Európai Bíróságának joggyakorlata a gyülölet-büncselekmények esetén folytatott büntetőeljárások tárgyában' (Case-law of the European Court of Human Rights regarding criminal procedures in hate crime cases) (2017) 58 Állam- és Jogtudomány Különszám (Special issue) 141-51. Lianos, M., 'Social Control after Foucault' (2003) 1 Surveillance and Society 412-30.

Möschel, M., 'Race in mainland European legal analysis: Towards a European Critical Race Theory' (2011) 34 Ethnic and Racial Studies 1648-64.

Möschel, M., Law, Lawyers and Race: Critical Race Theory from the US to Europe (Routlegde 2014).

Novoszádek, N. and Rácz, D., 'Gyülöletvezérelt büncselekmények európai szabályozási mintái' (The European Models of Hate Crime Regulation) (2009) 3-4 Föld-rész 63-80.

OSCE, ODIHR, Hate Crime Data-Collection and Monitoring Mechanisms: A Practical Guide (OSCE 2014).

OSCE, ODIHR, Preventing and responding to hate crimes: A resource guide for NGO's in the OSCE region (OSCE 2009).

Pap, A. L., 'The Working Group Against Hate Crimes: a unique good practice in Hungary' (2018) 17 European Law Enforcement Research Bulletin 85-90.

Perry, B. and Alvi, S., 'We are all vulnerable: The in terrorem effects of hate crimes' (2012) 18 International Review of Victimology 57-71.

Perry, B., 'Exploring the community impacts of hate crime' in Hall, N., Corb, A., Giannasi, P., Grieve, J. G. D. and Lawrence, N. (eds.), The Routledge International Handbook on Hate Crime (Routlegde 2014) 47-58.

Stuhlberg, J. B. and Love, L. P., The Middle Voice: Mediating Conflict Successfully (Carolina Academy Press 2013).

Zehr, H., The Little Book of Restorative Justice (Good Books 2002).

Open Access. This is an open-access article distributed under the terms of the Creative Commons Attribution 4.0 International License (https://creativecommons.org/licenses/by/4.0/), which permits unrestricted use, distribution, and reproduction in any medium, provided the original author and source are credited, a link to the CC License is provided, and changes - if any - are indicated. (SID_1) 